\title{
Polymorphism in the tumor necrosis factor-alpha gene (TNFA -308 G/A) is not associated with susceptibility to chronic periodontitis
} in a Brazilian population

Paula Cristina Trevilatto ${ }^{1}$, Rui Barbosa de Brito $\mathrm{Jr}^{2}$, Raquel Mantuaneli Scarel-Caminaga ${ }^{3}$, Ana Paula de Souza Pardo ${ }^{4}$, Cleber Machado de Souza ${ }^{1}$, Antonio Wilson Sallum ${ }^{4}$, Sérgio Roberto Peres Line ${ }^{4}$

${ }^{1}$ School of Health and Biosciences at Pontifícia Universidade Católica do Paraná (PUCPR), Curitiba, PR, Brazil

${ }^{2}$ São Leopoldo Mandic Dental Research Institute, Campinas, SP, Brazil

${ }^{3}$ Department of Diagnosis and Surgery, School of Dentistry, UNESP - São Paulo State University, Araraquara, SP, Brazil

${ }^{4}$ Department of Morphology, Dental School of Piracicaba, State University of Campinas, Piracicaba, SP, Brazil

\section{Abstract}

Objective: Tumor necrosis factor-alpha (TNF- $\alpha$ ) is a major mediator of the immuneinflammatory response and may play an important role in the pathogenesis and progression of chronic periodontitis. Polymorphisms in the promoter of the TNFA gene have been associated with some types of inflammatory diseases. The present study investigated the association between a single-nucleotide polymorphism (SNP) of the TNFA (G-308A) gene and chronic periodontitis in Brazilians. Methods: One hundred and thirteen (113) over 25 years were divided according to the severity level of periodontal disease: 44 healthy individuals (control group), 31 subjects with moderate and 38 patients with severe periodontitis. Genomic DNA was obtained from epithelial cells. The samples were analyzed for TNFA (G-308A) polymorphism using polymerase chain reaction-restriction fragment length polymorphism techniques. The significance of the differences in the genotype frequencies of the polymorphism was assessed by Chi-square test $(p<0.05)$. Results: No significant differences in the genotype distribution and allele frequency were found between control and groups with periodontitis. Conclusion: It was concluded that TNFA (-308) polymorphism was not associated with chronic periodontitis. Other polymorphisms in this or/and other genes of the host inflammatory response might be involved in determining susceptibility to periodontitis in the study population.
Citation: Trevilatto $P$, de Brito Jr. R, ScarelCaminaga R, Pardo A, de Souza C, Sallum A, Line S. (2015) Polymorphism in the tumor necrosis factor-alpha gene (TNFA - $308 \mathrm{G} / \mathrm{A}$ ) is not associated with susceptibility to chronic periodontitis in a Brazilian population. Dentistry 3000. 1:a001 doi:10.5195/d3000.2015.27

Received: September 24, 2014

Accepted: November 25, 2015

Published: December 18, 2015

Copyright: C2015 Trevilatto P, de Brito Jr. R, Scarel-Caminaga R, Pardo A, de Souza C, Sallum A, Line $S$. This is an open access article licensed under a Creative Commons Attribution Wor k 4.0 United States License.

Email: pctrev@yahoo.com.br

\section{Introduction}

Bacterial lipopolysaccaharides (LPS) activate monocytes of inflamed periodontal tissues to produce cytokines. Tumor necrosis factor-alpha (TNF- $\alpha$ ) is an important immune mediator and a pluripotent proinflammatory cytokine that is able to induce bone resorption [1].
TNFA gene is encoded on chromosome 6 inside the HLA region [2] and its biological activities have raised the possibility that polymorphisms within this gene might contribute to genetic association to diverse immune-inflammatory diseases. In fact, polymorphisms in TNFA gene have been implicated in the pathogenesis of a large number of human diseases. Within the pro- moter region of TNFA, a biallelic polymorphic site at position -308 has been reported to influence the production of TNF- $\alpha$ protein [3]. Allele A of TNFA (-308) polymorphism has been positively associated with asthma [4] and ulcerative colitis [5]. 
Vol 3, No 1 (2015) DOI 10.5195/d3000.2015.27

Table 1. Baseline clinical parameters of the subject population $(\mathrm{n}=113)$.

\begin{tabular}{|c|c|c|c|}
\hline & Healthy $(n=44)$ & Moderate $(n=31)$ & Severe $(n=38)$ \\
\hline \multicolumn{4}{|l|}{ Age (years) } \\
\hline Mean $( \pm$ SD $)$ & $43.2( \pm 14.0)$ & $36.9( \pm 11.2)$ & $43.6( \pm 14.4)$ \\
\hline \multicolumn{4}{|l|}{ Gender \% } \\
\hline Female & 68.2 & 80.6 & 84.2 \\
\hline Male & 31.8 & 19.4 & 15.8 \\
\hline \multicolumn{4}{|l|}{ Ethnic Group \% } \\
\hline Caucasian & 84.1 & 77.4 & 68.4 \\
\hline Afro-American & 6.8 & 16.1 & 13.2 \\
\hline Mulatto & 6.8 & 6.5 & 18.4 \\
\hline Japanese & 2.3 & 0.0 & 0.0 \\
\hline
\end{tabular}

Epidemiological studies indicate that chronic periodontitis (CP) is widespread among the Brazilian population $[6,7]$. TNFA mRNA was significantly more frequent in diseased than in healthy gingival biopsies [8], suggesting a role of this cytokine in the development of CP. Increased levels of TNF- $\alpha$ in periodontal tissues were associated with genotypes carrying allele A [9]. Because of the increasing evidence that genetic variations within the TNFA locus are important in determining susceptibility to periodontitis, this study aimed to investigate the possible link between the polymorphism at position $-308(\mathrm{G} \rightarrow \mathrm{A})$ of TNFA gene promoter and chronic periodontitis in a Brazilian population.

\section{Materials and Methods}

\section{Subject Selection}

A convenience sample of 113 unrelated, non-smoking subjects $>25$ years of age, were recruited for study from the patient pool at the Dental Clinics of the Faculty of Dentistry of Piracicaba - UNICAMP. The patients are from the South- eastern region of Brazil. The baseline clinical parameters for the subject population are presented in table 1.

All subjects were in good general health and had at least 20 teeth in the mouth. Subjects were not included if presented: diseases of the oral hard or soft tissues except caries and periodontal disease; use of orthodontic appliances; need for pre-medication for dental treatment; chronic usage of antiinflammatory drugs; a history of diabetes, hepatitis or HIV infection; immunosuppressive chemotherapy; history of any disease known to severely compromise immune function; present acute necrotizing ulcerative gingivitis or current pregnancy or lactation. Subjects completed personal medical and dental history questionnaires, and within a protocol approved by an Institutional Review Board, signed a consent form after being advised of the nature of the study (approved by the Ethical Committee in Research at FOP/UNICAMP, protocol 63/99).

Diagnosis and classification of disease severity were made on the basis of clinical parameters and consisted of physical examination, medical and dental history, probing depth, assessment of clinical attachment loss (CAL), tooth mobility, gingival recession and observation of bleeding on probing, according to Lindhe et al. [10]. Measurements of probing depth and attachment level were recorded at 6 points around each tooth. Subjects were included in clinical categories according to:

\section{CP severity:}

1) Healthy group: Subjects found to exhibit no signs of periodontal disease as determined by the absence of clinical attachment loss and no sites with probing depth $>3 \mathrm{~mm}$ (n $=44$ ) in at least 3 teeth in at least 2 different quadrants;

2) Moderate Periodontitis: Patients with tooth sites exhibiting $\geq 3 \mathrm{~mm}$ and $<7 \mathrm{~mm}$ CAL $(\mathrm{n}=31)$ in at least 3 teeth in at least 2 different quadrants;

3) Severe Periodontitis: Patients with teeth exhibiting $\geq 7 \mathrm{~mm}$ CAL (n $=38$ ) in at least 3 teeth in at least 2 different quadrants.

\section{Sampling}

The sampling of epithelial buccal cells was performed as described by Trevilatto and Line [11]. Briefly, 113 individuals undertook a mouthwash after $1 \mathrm{~min}$, containing $5 \mathrm{ml} \mathrm{3 \%}$ glucose. Following mouthwash, a sterile wood spatula was used to scrape oral mucosa. The tip of the spatula was then shaken into the retained mouthwash solution. Buccal epithelial cells were pelleted by centrifugation at $2000 \mathrm{rpm}$ for $10 \mathrm{~min}$. The supernatant was discarded and the cell pellet resuspended in $500 \mu \mathrm{l}$ of extraction buffer [10 mM Tris-HCl (pH 7.8), 5 mM EDTA, 0.5\% SDS]. The samples were then frozen at $-20 \mathrm{oC}$ until used for DNA extraction.

\section{DNA Extraction}


After defrosting, samples were incubated overnight (ON) with 100 $\mathrm{ng} / \mathrm{ml}$ proteinase K (Sigma Chemical Co., St. Louis, MO, USA) at $37^{\circ} \mathrm{C}$ with agitation. DNA was then purified by sequential phenol/chloroform extraction and salt/ethanol precipitation. DNA was dissolved in $70 \mu \mathrm{l}$ TE buffer $[10 \mathrm{mM}$ Tris $(\mathrm{pH}$ 7.8), 1 mM EDTA]. The concentration was estimated by measurements of OD 260.

\section{Polymerase Chain Reaction (PCR) and Restriction Fragment Poly- morphism (RFLP)}

Polymorphism in the TNF- $\alpha$ gene at position -308 (rs1800629) The oligonucleotides 5'AGGCAATAGGTTTTGAGGGCCAT-3' and 5'-TCCTCCCTGCTCCGATTCCG3'. Amplification reactions were performed with $500 \mathrm{ng}$ genomic DNA in a total volume of $50 \mu \mathrm{l}$, containing $10 \mathrm{mM}$ Tris- $\mathrm{HCl}$ (pH 8.3), 50 $\mathrm{mM} \mathrm{KCl}, 2 \mu \mathrm{M}$ of each primer, 200 $\mu \mathrm{M}$ each dATP, dCTP, dGTP and dTTP, and 2.5 units Taq DNA polymerase (Amersham Pharmacia Biotech, Uppsala, Sweden). Cycling was 2 cycles of $3 \mathrm{~min}$ at $94^{\circ} \mathrm{C}, 1 \mathrm{~min}$ at $60^{\circ} \mathrm{C}$ and $1 \mathrm{~min}$ at $72^{\circ} \mathrm{C}$, followed by 35 cycles of $1 \mathrm{~min}$ at $94^{\circ} \mathrm{C}, 1 \mathrm{~min}$ at $60^{\circ} \mathrm{C}$ and $1 \mathrm{~min}$ at $72^{\circ} \mathrm{C}$, with a final extension of $7 \mathrm{~min}$ at $72^{\circ} \mathrm{C}$. The products were digested with $3 \mathrm{U}$ per $25 \mu \mathrm{L}$ reaction of $\mathrm{NcoI}$ at $37^{\circ} \mathrm{C}$ ON to detect allele 1 [G] (20 bp +87 $\mathrm{bp}$ ) and allele $2[\mathrm{~A}]$ (107 bp).

\section{Electrophoresis gel}

Restriction products were visualized by electrophoresis on vertical $10 \%$ non-denaturing polyacrylamide gels in $1 \mathrm{X}$ TBE $(89 \mathrm{mM}$ Tris-Borate, $89 \mathrm{mM}$ boric acid, 2 mM EDTA), followed by silver staining (Bio-Rad Silver Stain Kit).
Statistical analysis

The allele ratio and genotype distribution of periodontitis patients and healthy control subjects were analyzed with Chi-square test. A pvalue $<0.05$ was considered significant.

\section{Results}

There was no significant difference in the genotype distribution $(\mathrm{p}=0.289)$ between healthy control and periodontitis patients in the polymorphism TNFA (-308), neither was observed statistical variation in the frequency of the alleles $(p=0.674)$. The distribution of the genotype and the frequencies of the alleles for the polymorphism studied are shown in tables 2 and 3 , respectively. Allele 2 was carried by $19.5 \%(22 / 113)$ of the subjects, with $1.8 \%(2 / 113)$ of homozygous.

The allele distribution in the study population was consistent with Hardy-Weinberg equilibrium. The moderate and severe groups (table 1) were combined and compared to the healthy group in order to seek a better biological explanation of the results. The results of analyzes of the additive model ( $\mathrm{p}=$ 0.503 ), a dominant model for the $\mathrm{L}$ $(\mathrm{p}=0.559)$ and for the recessive allele $G(p=0.255)$ allele were not significant.

\section{Discussion}

Because of their frequent presence in diseased sites, it has been postulated that cytokines such as interleukin-1 (IL-1) and TNF- $\alpha$ may be indicators of the active phase of periodontal disease [12]. Tumor necrosis factor-alpha, a proinflammatory cytokine, has been detected in gingival crevicular fluid and gingival tissues from individuals with periodontitis [13]. This cytokine is a potent immunologic mediator that, in addition to its inflammatory effects, increases bone resorption and regulates fibroblast proliferation [14].

A number of single nucleotide polymorphisms (SNPs) has been identified in the TNFA promoter and associated with certain chronic inflammatory diseases, including cerebral malaria [15], multiple sclerosis [16], ulcerative colitis [17], Alzheimer's disease [18], chronic bronchitis [19] and rheumatoid arthritis [20]. In cerebral malaria TNF- $\alpha$ is of major importance for the pathology [15] and individuals homozygous for the TNFA (-308) A allele carry a 7-fold higher risk of death or severe neurological sequelae due to cerebral malaria.

In this study, no association of TNFA (-308) polymorphism with $\mathrm{CP}$ was found. However, in another Brazilian population, Trombone et al. [9] found a frequency (17.7\%) of the TNFA (-308) A allele in the CP group. Kornman et al. [21] found an allele A carriage rate of $28.5 \%$ at 
Table 3. Distribution of the TNF- $\alpha$ alleles in healthy, moderate and severe groups with chronic periodontitis.

\begin{tabular}{lccccc}
\hline \multirow{2}{*}{ Allele } & \multicolumn{2}{c}{ Healthy } & \multicolumn{2}{c}{ Moderate } & \multicolumn{2}{c}{ Severe } & \multirow{2}{*}{$\mathbf{p}$ value } \\
\hline $\mathbf{G}$ & 81 & $\mathbf{( \% )}$ & $\mathbf{n}(\mathbf{\%})$ & $\mathbf{n}(\mathbf{\%})$ & 0.674 \\
$\mathbf{A}$ & $7(8.0)$ & $55(88.7)$ & $67(88.0)$ & \\
& & $7(11.3)$ & $9(12.0)$ &
\end{tabular}

TNFA (-308) locus in North-

American Caucasians, but no association with CP. We found an allele A carriage rate of $20.7 \%$ (18/87) for our Caucasians.

Although the study sample was mostly composed by Caucasians, the Brazilian white population is heterogeneous. Recent article has not suggested grouping Brazilians into ethnic groups based on color, race and geographical origin because Brazilian individuals classified as white or black have significantly overlapping genotypes, probably due to miscegenation [22]. Reporting the Caucasoid population, there is a predominance of Italian, Spanish, and Portuguese heritage. In a meta-analysis by $\mathrm{Ni}$ kolopoulos et al. [23] the great majority of studies were carried out in Caucasian populations and no association of TNFA (-308) was found neither with aggressive nor chronic periodontal diseases. A lack of association of this polymorphism in patients with early-onset periodontitis was also found in a Japanese population [24]. However, Lin et al. [25] observed that allele A may increase the odds of having moderate-toadvanced aggressive periodontitis. Galbraith et al. [26] reported the frequency of TNFA $(-308)$ allele G significantly greater in patients with advanced periodontitis. Recently, a new meta-analysis study was performed [27] and stratification by ethnicity showed that the A allele was associated with periodontitis in Brazilians, in spite of the lack of association showed in the studies in- cluded in the meta-analysis for $\mathrm{CP}$ [28-30].

There has been an evidence that allele $\mathrm{A}$ is over-represented in diseases where TNF- $\alpha$ levels are associated with poor prognosis [31]. Allele A of TNFA (-308) polymorphism seems to be associated to increase in the production of TNF- $\alpha$ cytokine [9]. Although the role TNF$\alpha$ plays in leading to tissue destruction, it is worth mentioning the need for evaluation of other potential candidate genes as contributors to periodontitis, since chronic periodontitis may possibly represent a polygenic disease.

Analysis in some of other study cytokine genes (IL4, MMP1, VDR, IL1) revealed positive associations with chronic periodontitis in the same Brazilian patients [32-35]. Those studies may provide pieces of information with regard to which factors could indeed be implicated in the process of disease in this population. In spite of the reduced number of individuals in each group, it seems that this sample was composed of well characterized phenotypes, once positive associations could be identified for some gene polymorphisms in previous studies [33, 35, 36]. Besides, only a small functional part of the gene was investigated, which does not mean that this gene could not be involved in the susceptibility control of chronic periodontitis. Thus, an investigation of tag SNPs, which physically represent the gene as a whole, should be recommended.

It was concluded that TNFA $(-308)$ polymorphism was not asso- ciated with chronic periodontitis in the population studied.

\section{Acknowledgements}

This study was supported by FAPESP grants 99/05610-2 and 99/06094-8. There are no conflicts of interest to report.

\section{References}

1. Proinflammatory cytokines and osteoporosis. McLean RR. Curr Osteoporos Rep. 2009 Dec;7:134-9. PMID: 19968917.

2. An allelic polymorphism within the human tumor necrosis factor alpha promoter region is strongly associated with HLA A1, B8, and DR3 alleles. Wilson AG, de Vries N, Pociot F, di Giovine FS, van der Putte LB, Duff GW. J Exp Med. 1993 Feb;177:557-60. PMID: 8426126.

3. Effects of a polymorphism in the human tumor necrosis factor alpha promoter on transcriptional activation. Wilson AG, Symons JA, McDowell TL, McDevitt HO, Duff GW. Proc Natl Acad Sci USA. 1997 Apr;94:3195-9. PMID: 9096369.

4. The specific features of TNFalpha gene polymorphism in asthmatic patients and their relatives. Cherkashina II, Nikulina S, Logvinenko NI, Voevoda MI, Maksimov VN, Liberdovskaia ED. Probl Tuberk Bolezn Legk. 2009;8:51-6. PMID: 19803352.

5. Polymorphisms in the promoter region of tumor necrosis factor alpha (TNF-alpha) and the HLA-DRB1 locus in Mexican mestizo patients 
with ulcerative colitis. YamamotoFurusho JK, Uscanga LF, VargasAlarcón G, Rodríguez-Pérez JM, Zuñiga J, Granados J. Immunol Lett. 2004;95:31-5. PMID: 15325795.

6. Prevalence of bone loss in a group of Brazilian teenagers assessed on bite-wing radiographs. Gjermo, P. Bellini, H.T. Pereira Santos V, Martins JG, Ferracyoli JR. J Clin Periodontol. 1984;11:104-13. PMID: 6583209.

\section{Periodontal conditions and} treatment needs (CPITN) in a worker population in Araraquara, SP, Brazil. Dini EL, Guimaraes LO. Int Dent J. 1994;44:309-11. PMID: 7822055.

8. Quantitative assessment of inflammatory cytokine gene expression in chronic adult periodontitis. Roberts FA, Hockett RD, Bucy RP, Michalek SM. Oral Microbiol Immunol. 1997;12:336-44. PMID:

9573807.

9. Tumor necrosis factor-alpha 308G/A single nucleotide polymorphism and red-complex periodontopathogens are independently associated with increased levels of tumor necrosis factor-alpha in diseased periodontal tissues. Trombone AP, Cardoso CR, Repeke CE, Ferreira SB, Martins W, Campanelli AP, Avila-Campos MJ, Trevilatto PC, Silva JS, Garlet GP. J Periodontal Res. 2009;44:598-608. PMID: 19076989.

10. Consensus Report: Chronic Periodontitis. Lindhe J, Lamster RI, Charles A, Chung CP, Flemmig T, Kinane D. Ann Periodontol. 1999;4:38.
11. Use of Buccal Epithelial Cells for PCR Amplification of Large DNA Fragments. TrevilattoPC, Line SRP. J Forensic Odontostomatol. 2000;18:6-9. PMID: 11324090.

12. Gene polymorphisms in proinflammatory cytokines are associated with systemic inflammation in patients with severe periodontal infections. D'Aiuto F, Parkar M, Brett PM, Ready D, Tonetti MS. Cytokine. 2004;28:29-34. PMID: 15341923.

13. Role of cytokines and inflammatory mediators in tissue destruction. Birkedal-Hansen H. J Periodontal Res. 1993;28:500-10. PMID: 8263720.

14. Role of cytokines in bone resorption. Manolagas SC. Bone. 1995; 17:63S-67S. PMID: 8579900.

15. Cytokines and adhesion molecules expression in the brain in human cerebral malaria. Armah $\mathrm{H}$, Wired EK, Dodoo AK, Adjei AA, Tettey Y, Gyasi R. Int J Environ Res Public Health. 2005;2:123-31. PMID: 16705810.

16. IL-1, IL-1R and TNFalpha gene polymorphisms in Iranian patients with multiple sclerosis. Sarial S, Shokrgozar MA, Amirzargar A, Shokri F, Radfar J, Zohrevand P, Arjang Z, Sahraian MA, Lotfi J. Iran J Allergy Asthma Immunol. 2008;7:37-40. PMID: 18322311.

17. Effect of the polymorphism of tumor necrosis factor-alpha-308 G/A gene promoter on the susceptibility to ulcerative colitis: a metaanalysis. Lu Z, Chen L, Li H, Zhao Y,
Lin L. Digestion. 2008;78:44-51. PMID: 18827481.

18. Systematic review by metaanalyses on the possible role of TNF-alpha polymorphisms in association with Alzheimer's disease. Di Bona D, Candore G, Franceschi C, Licastro F, Colonna-Romano G, Cammà C, Lio D, Caruso C. Brain Res Rev. 2009;61:60-8. PMID: 19445962.

19. Nuclear factor kappaB-mediated down-regulation of adhesion molecules: possible mechanism for inhibitory activity of bigelovin against inflammatory monocytes adhesion to endothelial cells. Nam KW, Oh GT, Seo EK, Kim KH, Koo U, Lee SJ, Mar W. J Ethnopharmacol. 2009;123:250-6. PMID: 19429369.

20. Associations Between Tumor Necrosis Factor-\{alpha\} (TNF\{alpha\}) -308 and -238 G/A Polymorphisms and Shared Epitope Status and Responsiveness to TNF\{alpha\} Blockers in Rheumatoid Arthritis: A Metaanalysis Update. Lee YH, Ji JD, Bae SC, Song GG. J Rheumatol. 2010;37:740-6. PMID: 20194454.

21 . The interleukin-1 genotype as a severity factor in adult periodontal disease. Kornman KS, Crane A, Wang HY, Di Giovine FS, Newman MG, Pirk FW, Wilson Jr TG, Higginbottom FL, Duff GW. J Clin Periodontol. 1997;24:72-77. PMID: 9049801.

22. Color and genomic ancestry in Brazilians. Parra, F.C. Amado, R.C. Lambertucci JR, Rocha J, Antunes CM, Pena SD. Proceedings of the Na- 
tional Academy of Sciences of the United States of America. 2003;100:177-82. PMID: 12509516.

23. Cytokine gene polymorphisms in periodontal disease: a metaanalysis of 53 studies including 4178 cases and 4590 controls. Nikolopoulos GK, Dimou NL, Hamodrakas SJ, Bagos PGJ. Clin Periodontol. 2008;35:754-67. PMID:

18673406.

24. Analysis of single nucleotide polymorphisms in the 5 '-flanking region of tumor necrosis factoralpha gene in Japanese patients with early-onset periodontitis. Endo M, Tai H, Tabeta K, Kobayashi T, Yamazaki K, Yoshie H. J Periodontol. 2011;72:1554-9. PMID: 11759867.

25 . Study on the correlation of cytokine gene polymorphism with chronic periodontitis. Lin L, Pan YP, Yin LY. Shanghai Kou Qiang Yi Xue. 2003;12:456-9. PMID: 14966591.

26. Polymorphic cytokine genotypes as markers of disease severity in adult periodontitis. Galbraith GMP, Hendley TM, Sanders JJ, Palesch Y, Pandey JP. J Clin Periodontol. 1999; 26:705-9. PMID: 10589805.

27. Association between tumor necrosis factor- $\alpha$ promoter $-308 \mathrm{~A} / \mathrm{G}$, 238 A/G, interleukin-6 -174 G/C and $-572 \mathrm{G} / \mathrm{C}$ polymorphisms and periodontal disease: a metaanalysis. Song GG, Choi SJ, Ji JD, Lee YH. Mol Biol Rep. 2013;40:5191203. PMID: 23657600.

28. Interleukin-6 (G-174C) and tumour necrosis factor-alpha (G-
308A) gene polymorphisms in geriatric patients with chronic periodontitis. Costa AM, Guimarães MC, de Souza ER, Nóbrega OT, Bezerra AC. Gerodontology. 2010;27(1):705. PMID: 19555357.

29. Lack of association between the TNF-alpha -308 (G/A) genetic polymorphism and periodontal disease in Brazilians. Menezes NG, Colombo AP. Braz Oral Res. 2008;22(4):3227. PMID: 19148387.

30. Analysis of IL-1A(-889) and TNFA(-308) gene polymorphism in Brazilian patients with generalized aggressive periodontitis. Maria de Freitas N, Imbronito AV, Neves AC, Nunes FD, Pustiglioni FE, Lotufo RF. Eur Cytokine Netw. 2007;18(3):142-7. PMID: 17823082.

31. TNF concentration in fatal cerebral, non-fatal cerebral, and uncomplicated Plasmodium falciparum malaria. Kwiatkowski D, Hill AV, Sambou I, Twumasi P, Castracane J, Manogue KR, Cerami A, Brewster DR, Greenwood BM. Lancet. 1990;336:1201-4. PMID: 1978068.

32. Frequencies of the $-330(\mathrm{~T}-->\mathrm{G})$ IL-2 and -590 (T --> C) IL-4 gene polymorphisms in a population from south-eastern Brazil. ScarelCaminaga RM, Trevilatto PC, Souza AP, Brito RB, Line SR. Eur J Immunogenet. 2002;29:293-6. PMID: 12121273.

33. MMP-1 promoter polymorphism: association with chronic periodontitis severity in a Brazilian population. de Souza AP, Trevilatto
PC, Scarel-Caminaga RM, de Brito RB, Line SR. J Clin Periodontol. 2003;30:154-8. PMID: 12622858.

34. Polymorphisms in the vitamin D receptor gene are associated with periodontal disease. Brito Júnior RB, Scarel-Caminaga RM, Trevilatto PC, de Souza AP, Barros SP. J Periodontol. 2004;75:1090-95. PMID: 15455736.

35. Association of IL1 gene polymorphisms with chronic periodontitis in Brazilians. Trevilatto PC, de Souza Pardo AP, Scarel-Caminaga RM, de Brito Jr RB, Alvim-Pereira F, Alvim-Pereira CC, Probst CM, Garlet GP, Sallum AW, Line SR. Arch Oral Biol. 2011;56:54-2. PMID: 20934174.

36. Polymorphism at position -174 of IL- 6 gene is associated with susceptibility to chronic periodontitis in a Caucasian Brazilian population. Trevilatto PC, Scarel-Caminaga RM, de Brito RB Jr, de Souza AP, Line SR. J Clin Periodontol. 2003;30(5):43842. PMID: 12716337. 